\title{
THE NORTHERN SEA ROUTE, ECOSYSTEMS, NATURE-LIKE TECHNOLOGIES, SCIENCE AND EDUCATION, CONFLICTS DURING THE DEVELOPMENT OF THE NINTH TECHNOLOGICAL ORDER
}

\author{
V.V. Glushchenko ${ }^{1} \square$ (iD \\ Doctor of Technical Sciences, Associate Professor, Moscow, Russia.
}
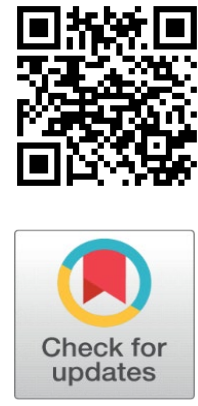

Received 1 September 2021

Accepted 15 September2021

Published 4 December 2021

CorrespondingAuthor

V.V. Glushchenko,

valery.v.glushchenko@gmail.com

DOI 10.29121/IJOEST.v5.i6.2021.250

Funding: This research received no specific grant from any funding agency in the public, commercial, or not-for-profit sectors.

Copyright: (C) 2021 The Author(s). This is an open access article distributed under the terms of the Creative Commons Attribution License, which permits unrestricted use, distribution, and reproduction in any medium, provided the original author and source are credited.

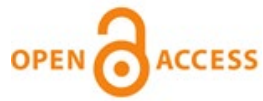

\section{ABSTRACT}

The subject of the article is the development of ecosystems, science and education during the development of the ninth technological order (NTO); the object of the article is the national innovation system; the purpose of the work is to improve the efficiency of management of the development of NTO; to achieve this goal, the following tasks are solved: a methodology for the system analysis of the transport sector and the ecosystem of the Sulfur Sea Route in NTO is formed; an analysis of the risks of the development of NTO and ecosystems is carried out; the role of science and education in the process of creating ecosystems and the development of NTO is investigated; the necessity of advanced development, the main trends in the development of science and education during the NTO period are substantiated; mental conflicts during the NTO period are studied; the scientific methods of the article are system engineering; the theory of scientific and technical forecasting, the theory of hierarchical systems, historical, system analysis, synthesis, heuristic methods, logic, expert methods, conflictology; the theory of efficiency; the scientific novelty of the work is determined by the development of NTO system engineering methods, the formation of an ecosystem approach to the modernization of the Northern Sea Route based on NTO scientific achievements.

Keywords: Science, Education, Ecosystem, Ninth Technological Order (ETO). Transport, System Analysis, Conflict, Northern Sea Route (NSR), Program, Efficiency, Modernization, System

\section{INTRODUCTION}

The relevance of this article is related to the need to study the role of science and education in the development and modernization of the international transport corridor "Northern Sea Route" in the process of forming the ninth technological order (NTO). The advanced development of science and education is the methodological basis for the synthesis of the image of the future NTO. A special case of the future appearance of NTO is the development of ecosystems. It is proposed to develop ecosystems of international transport corridors: the Northern Sea Route (NSR); the BaikalAmur Mainline, the Great Silk Road and others.

The synthesis of the appearance of the future ecosystems should be carried out within the framework of a systematic approach by the method of forecasting. The image of the future of the NSR ecosystem means: the structure of the NSR; the main performance indicators of the NSR in the 
period of the new technological order. Such a synthesis of the appearance of the future NSR is carried out on the basis of a system analysis of the essence of NTO. Creating such an image of the future of NTO, NTO ecosystems will help determine development goals. This will make it possible to make more informed investment and management decisions in the process of forming the NTO, NSR development program for the period up to 2040.

The hypothesis of the article is the statement that the advanced development of science and education will increase the efficiency of investments in the development of NTO, NSR and, at the same time, reduce the risks of the development of NTO, and other NTO projects, in particular NSR.

The purpose of the work is to increase the efficiency of NTO development management.

To achieve this goal, the following tasks are solved:

- the methodology of the system analysis of the transport sphere and the ecosystem of the NSR in NTO is being formed;

- an analysis of the risks of the development of NTO and ecosystems is carried out;

- the role of science and education in the creation of ecosystems and the development of NTO is being investigated;

- substantiates the need for advanced development, the main trends in the development of science and education during the NTO period;

- mental conflicts during the development of NTO are studied.

The object of the article is the national innovation system.

The subject of the article is the development of ecosystems, science and education during the development of the ninth technological order (NTO).

The analysis of scientific articles on the topic of this work shows that the study of technological orders (structures) is an important international topic of scientific research Arrighi (1994), Aivazov (2012), Glazyev (2016). System analysis is considered as an effective tool in the activities of firms Shakhbanov and Azizova (2019). The method of system analysis is actively used to build a model and to study the features of a new technological order Glushchenko (2021). The analysis shows the existence of mutual influence of modernization and transport Macheret (2021). Foreign scientists study the problems of managing the behavior of transport companies Protsenko (2020). In the course of historical development, the modernization of transport is considered as a factor and a tool to accelerate the modernization of the whole country Vasiliev and Mazaev (2020). It is believed that the lack of timely modernization of transport systems can lead to a socio-economic crisis Gnatyuk (2015). Scientists are developing problems of modernization of certain types of transport Gerasimenko (2020). Important tasks are considered to be the study of such areas of transport modernization: problems of legislative regulation of modernization of water transport Semenov et al. (2021); problems of modernization of certain types of transport equipment Vladimirov (2016). For the modernization of various transport systems, the scientific theory of transport systems can be used Glushchenko (2019). In the process of modernization of transport systems, the scientific theory of technological orders plays an important role Glushchenko (2021). In the process of forming a new technological order, new conceptual approaches to the synthesis of man-made objects will be important: the ecosystem approach Borovik and Doroshenko (2020); convergent (nature-like) technologies Kovalchuk (2021). The most general methodology for designing 
transport systems and transport corridors can be the theory of multilevel hierarchical systems Mesarovich et al. (1973). Strategic planning of the transition of firms to a new technological order remains an important tool for ensuring the competitiveness of firms Glushchenko (2021). The development of neurotechnologies in management remains an important structural element of the new technological order Glushchenko (2017). At the same time, new institutional relations should also develop in the economy Glushchenko (2021). The development of a new technological order is accompanied by discussions and conflicts Kolchinsky et al. (2018). The expansion of the scale of scientific and innovative activities should be accompanied by their customization Glushchenko (2021). It is predicted that the project approach in science and education will receive its further development Glushchenko (2021). The research of scientific articles on the topic of this work carried out in this article confirms its relevance.

\section{METHOD}

System engineering can be considered as a methodological basis for: shaping the image of the future; macro-designing the modernization of the Northern Sea Route. This kind of engineering is a practical direction of system integration (aggregation) of a number of scientific disciplines: theory of technological structures; financial management; theory of hierarchical systems; theory of transport systems; economic theory; conflictology; theories of management and marketing and others. System engineering can be applied in solving the problems of practical implementation of the modernization of the NSR based on technologies of the 9th technological order (NTO).

The ecosystem of the NSR will be called an integrated transport system that meets the following requirements: ensuring the transit passage of international passenger and cargo flows; meeting the transport needs of adjacent regions; rational use of existing assets; minimizing environmental damage in the process of functioning; maximally satisfying the needs of stakeholders, taking into account the possible inconsistency of these requirements, and more. At the same time, the international transport corridor should be integrated with the system of interregional communications of the adjacent regions of the country.

The concept of an ecosystem approach to the modernization of the NSR will be called a systematic view of the modernization of the NSR and its results. The image of the future of the NSR can be called: the structure of the NSR; the main characteristics of the activities of the NSR after its planned modernization.

The image of the future NSR may consist of a description of its structural elements: the flow of international goods; the flow of goods between regions of one country; characteristics of environmental pollution; factors influencing the socioeconomic development of adjacent regions (economic growth rates, the zamount of payments to the budget of the region, the number of jobs in the region, etc.). The flows of passengers and cargo (transit and between regions) can be described by the following indicators: the volume of traffic, the probability of passenger injury, the average speed of cargo movement, reliability, the probability of cargo loss, etc.

In the process of preparing the SMP modernization project, it is proposed to compile two lists (internal and external) of interested persons.

During the process of designing the ecosystem of the Northern Sea Route transport corridor, it is proposed to compile a general list of requirements for this ecosystem from its stakeholders. To do this, it is necessary to conduct a survey of all stakeholders: government agencies; cargo owners, representatives of the navy, consignees, government agencies, municipal authorities, transport companies, 
residents of regions and others. Such a survey is conducted in the interests of forming a set of requirements for such an ecosystem. After conducting such a survey, the results obtained should be processed and analyzed. During such processing of the survey results, all matching requirements for the ecosystem of different stakeholders should be highlighted in the first list. The requirements from this first list should be implemented in full. The second list is proposed to include alternative (mutually exclusive) requirements of different stakeholders. Such conflicting ecosystem requirements from this second list should be studied in order to ensure that a reasonable compromise is reached between such conflicting requirements.

Modernization of ecosystems of international transport corridors (NSR, BAM, the Great Silk Road, etc.) should correspond to the general direction of scientific and technological progress in the transport industry.

An analysis of the development of transport has shown that the first technological order (way) can be called the technological order, which is associated with the invention of the sail. On this basis, the numbering of technological orders can be changed. As part of the new numbering, the new technological order gets No. 9 (the ninth technological order (way)).

Presumably, the invention of the sail can be attributed to the category of the first prorid-like (convergent) technologies.

To assess the trends in the development of the transport industry, we will conduct a systematic analysis of this development, the results of which are reflected in Table 1. Such an analysis is of a demonstration and indicative nature, and therefore requires clarification from experts in the field of transport history.

Table 1 System analysis of the development of the transport industry in the course of scientific and technological progress

\begin{tabular}{|c|c|c|c|c|}
\hline $\begin{array}{c}\text { № } \\
\text { П/ா }\end{array}$ & $\begin{array}{l}\text { Properties of } \\
\text { technological } \\
\text { structures on } \\
\text { transport /Number } \\
\text { technological order, } \\
\text { time period, name }\end{array}$ & $\begin{array}{c}\text { Nature and } \\
\text { properties of } \\
\text { transport systems }\end{array}$ & $\begin{array}{l}\text { New modes of } \\
\text { transport }\end{array}$ & $\begin{array}{c}\text { Mission, } \\
\text { methodology of } \\
\text { development of } \\
\text { transport } \\
\text { systems }\end{array}$ \\
\hline 1 & $\begin{array}{c}\text { 1st technological } \\
\text { order, } 5500 \mathrm{BC}-2000 \\
\text { BC., the invention of } \\
\text { the sail }\end{array}$ & $\begin{array}{l}\text { irregular transport } \\
\text { links }\end{array}$ & $\begin{array}{l}\text { the invention of } \\
\text { the sail }\end{array}$ & $\begin{array}{l}\text { common sense, } \\
\text { solving military } \\
\text { and economic } \\
\text { problems }\end{array}$ \\
\hline 2 & $\begin{array}{l}\text { 2st technological } \\
\text { order, } 2000 \text { BC. - IX } \\
\text { century AD; Horse- } \\
\text { drawn traction }\end{array}$ & $\begin{array}{l}\text { Local, irregular } \\
\text { transport links }\end{array}$ & $\begin{array}{l}\text { Horse-drawn } \\
\text { transport, rowing } \\
\text { fleet }\end{array}$ & $\begin{array}{l}\text { Common sense, } \\
\text { profitable trading }\end{array}$ \\
\hline 3 & $\begin{array}{l}\text { 3nd technological } \\
\text { order, IX century - } \\
\text { 1770; Water, wind } \\
\text { (windmill), mill }\end{array}$ & $\begin{array}{l}\text { Maritime trade, } \\
\text { intercontinental } \\
\text { expeditions }\end{array}$ & $\begin{array}{l}\text { Development of } \\
\text { the sailing fleet }\end{array}$ & $\begin{array}{c}\text { Trade, } \\
\text { development of } \\
\text { new lands }\end{array}$ \\
\hline 4 & $\begin{array}{l}\text { 4rd technological } \\
\text { order, 1770-1830; } \\
\text { Textile machines }\end{array}$ & $\begin{array}{l}\text { Intercontinental } \\
\text { water transport } \\
\text { corridors }\end{array}$ & $\begin{array}{l}\text { Development of } \\
\text { the sailing fleet }\end{array}$ & $\begin{array}{l}\text { Colonization of } \\
\text { territories, } \\
\text { creation of } \\
\text { empires }\end{array}$ \\
\hline 5 & $\begin{array}{l}\text { 5th technological } \\
\text { order, 1830-1880; } \\
\text { Steam engine }\end{array}$ & $\begin{array}{l}\text { Creation of railway } \\
\text { transport networks }\end{array}$ & $\begin{array}{l}\text { Steam water and } \\
\text { rail transport }\end{array}$ & $\begin{array}{l}\text { Regular transport } \\
\text { links along the } \\
\text { routes }\end{array}$ \\
\hline 6 & $\begin{array}{l}\text { 6th technological } \\
\text { order, 1880-1930; } \\
\text { Internal Combustion } \\
\text { Engine, Electric motor, }\end{array}$ & $\begin{array}{l}\text { Creation of an } \\
\text { aviation and } \\
\text { automobile } \\
\text { transport network }\end{array}$ & $\begin{array}{l}\text { Air fleet, airplanes, } \\
\text { balloons, road } \\
\text { transport }\end{array}$ & $\begin{array}{c}\text { Economic analysis } \\
\text { of transport } \\
\text { operations, } \\
\text { competition of }\end{array}$ \\
\hline
\end{tabular}




\begin{tabular}{|c|c|c|c|c|}
\hline 7 & $\begin{array}{l}\text { 7th technological } \\
\text { order, 1930-1970; } \\
\text { nuclear reactor, } \\
\text { computers, }\end{array}$ & $\begin{array}{l}\text { Globalization of } \\
\text { transport networks } \\
\text { and modes of } \\
\text { transport }\end{array}$ & $\begin{array}{c}\text { Nuclear Icebreaker } \\
\text { and submarine } \\
\text { Fleet }\end{array}$ & $\begin{array}{l}\text { construction of } \\
\text { airfields, } \\
\text { highways, a } \\
\text { systematic } \\
\text { approach, }\end{array}$ \\
\hline 8 & $\begin{array}{l}\text { 8-my technological } \\
\text { order (way), 1970- } \\
\text { 2010; microelectronics }\end{array}$ & $\begin{array}{l}\text { Formation of global } \\
\text { and national } \\
\text { transport systems }\end{array}$ & $\begin{array}{l}\text { high-speed rail } \\
\text { transport, radio- } \\
\text { electronic } \\
\text { navigation and } \\
\text { communication } \\
\text { systems }\end{array}$ & $\begin{array}{l}\text { Development of } \\
\text { transport logistics, }\end{array}$ \\
\hline 9 & $\begin{array}{l}\text { 9th technological } \\
\text { order, 2010-2040; } \\
\text { Neurotechnology, } \\
\text { nanotechnology, IT } \\
\text { technologies, resource- } \\
\text { saving technologies, } \\
\text { etc. }\end{array}$ & $\begin{array}{l}\text { Integrated transport } \\
\text { service systems for } \\
\text { customer needs, } \\
\text { improving the } \\
\text { quality of transport } \\
\text { services }\end{array}$ & $\begin{array}{c}\text { Hybrid and } \\
\text { unmanned } \\
\text { vehicles, improving } \\
\text { the comfort and } \\
\text { safety of transport } \\
\text { systems }\end{array}$ & $\begin{array}{l}\text { Theory of } \\
\text { transport systems, } \\
\text { ecosystem } \\
\text { approach and } \\
\text { convergent } \\
\text { technologies in the } \\
\text { field of transport }\end{array}$ \\
\hline
\end{tabular}

Source: developed by the author

In 2021, the methods of generating innovative ideas for the implementation of transport system modernization projects can be: ecosystem approach; theory of transport systems; method of "morphological analysis (box)"; method of analogy; convergent technologies; collective generation of ideas; brainstorming and more.

The conceptual approach to the search for ideas for the modernization of the NSR may consist in the fact that the idea of the NSR modernization project can be: synthesized by the method "from a general concept to a private engineering solution" (deductive method); induction method (from private to general); based on a certain philosophical concept of the development of transport technology (for example, the concept of eco-friendly or unmanned transport); based on the concept of the development of the 9th technological order in the economy and society; based on the goal of achieving greater comfort and safety for society, the individual.

The principles of modernization of international transport corridors in the NTO can be considered the principles of: provision of integrated transport services; simultaneous or sequential use of a number of modes of transport (merchant marine; icebreaker fleet; air transport, etc.); efficient use of vehicles; meeting the needs of stakeholders (cargo owners, the state, regions, local communities, etc.); minimizing environmental damage; improving the comfort and safety of life of the local community; centralized logistics service of transport flows, etc.

During the formation of the strategic plan for the modernization of the Northern Sea Route (NSR), it can be studied simultaneously as:

1) international and inland sea transport corridor within the framework of the general theory of transport systems;

2) a system-forming element in the ecosystem of the Far North of Russia, uniting a number of its regions (creation of a man-made superecosystem).

Presumably, as a result of such scientific work and modernization based on technologies of a new technological order, the overall socio-economic efficiency of all subjects of the Far North of Russia, including the NSR, can be increased, which can give a synergetic effect. 
Indicators of the effectiveness of the strategic plan for the modernization of the NSR can be called:

- increasing the level of versatility of the Northern Sea Route (passenger and cargo international transportation; regional transportation; tourism; northern delivery; export of products of the regional economy; increasing the pace of socio-economic development, etc.);

- increasing the level of safety and reliability of the functioning of the Northern Sea Route as an international and interregional transport corridor;

- ensuring an increase in the level of connectivity of Russia's regions, which will increase its geopolitical stability;

- increasing the loyalty of the local population as a result of increasing the level of safety and comfort of living conditions of the small peoples of the North while preserving their traditional ecosystems and lifestyle;

- minimization of disproportions in socio-economic development and living standards of the population of various regions of Russia;

- increasing the level of security of our country and ensuring increased state control over fauna, flora, minerals in these territories and more.

At the same time, the development of an ecosystem approach, new technologies and their use creates new technological opportunities for the development of the ecosystem of the Northern Sea Route (NSR) Borovik and Doroshenko (2020), Kovalchuk (2021).

To increase the level of validity of the strategic plan for the modernization of a technogenic facility, a SWOT analysis can be carried out. Such an analysis will reveal: threats and opportunities of the external environment; strengths and weaknesses of the modernization object.

At the same time, the strategic plan (or program) for the modernization of the facility may include the following groups of activities:

- measures aimed at adapting the modernization object (NSR, region, enterprise) to the threats of the external environment;

- measures aimed at using the modernization object of the opportunities that open up in the 9th technological order;

- measures (projects) to modernize the products of the modernization facility (NSR, region) of the enterprise through the use of technologies of the 9 th technological order (NTO);

- measures to modernize the production facilities of the modernization facility through the use of technologies of the 9th technological order.

As measures aimed at adapting the object of modernization to the threats of the external environment, we can name: branding and rebranding of the enterprise; updating the company's product basket; increasing the level of customer orientation of the company; introduction of lean production methodology; introduction of participatory management; development of the organizational culture of the company as a factor of ensuring competitiveness; management of social development of personnel, etc.

Activities aimed at using the environmental capabilities of the object of modernization can cover: the use of an ecosystem approach; the creation of nature- 
like (convergent) technologies; the application of the theory of technological patterns; ensuring multiple use (animation) of achievements of the 9th technological order (neurotechnology, nanotechnology, information technology, resource-saving technologies, etc.); the use of post-industrial marketing methods; morphological analysis; collective generation of ideas and more.

Currently, the methodologies of the ecosystem approach and convergent technologies in transport have not yet been developed. This creates certain risks when implementing ecosystem projects.

Even less is known about the proposal to develop nature-like (convergent) technologies. In his speeches, the author of this proposal emphasizes such features (criteria) for classifying technology as nature-like (convergent) technologies:

1) the presence of a certain analogy or similarity between artificially created technology and natural natural processes;

2) the focus of the technology on reducing the waste of the production process;

3) the possibility of recycling the waste of the production process by natural methods for nature;

4) reducing the cost of public labor to achieve a certain result of the production process?

The analysis shows that the technology of transporting people and cargo on a sailing vessel can fit this set of criteria?

In order to further clarify the similarities and distinctive features of a number of conceptual approaches in the development of new technologies, this paper proposes to conduct a comparative analysis of various conceptual approaches. It is possible to conduct a comparative analysis of marketing, ecosystem and nature-like (convergent) approaches, the concept of technological orders in the innovation sphere. Such a comparative analysis is reflected in Table 2.

Table 2 Comparative analysis of methodologies: concepts of efficiency of technological orders, marketing, ecosystem approach and convergent technologies

\begin{tabular}{|c|c|c|c|c|c|}
\hline $\begin{array}{c}\text { № } \\
\text { п/п }\end{array}$ & $\begin{array}{c}\text { Innovative } \\
\text { project } \\
\text { development } \\
\text { concepts /Titles } \\
\text { properties of } \\
\text { the concept }\end{array}$ & $\begin{array}{l}\text { Theory of } \\
\text { Marketing }\end{array}$ & $\begin{array}{l}\text { Theory of } \\
\text { economic } \\
\text { efficiency of } \\
\text { technological } \\
\text { orders }\end{array}$ & $\begin{array}{l}\text { The concept of } \\
\text { an ecosystem } \\
\text { approach }\end{array}$ & $\begin{array}{l}\text { The concept of } \\
\text { convergent } \\
\text { (nature-like) } \\
\text { technologies }\end{array}$ \\
\hline 1 & $\begin{array}{c}\text { The satisfied } \\
\text { need of society }\end{array}$ & $\begin{array}{l}\text { Individual } \\
\text { needs, market } \\
\text { segment } \\
\text { needs }\end{array}$ & $\begin{array}{l}\text { Society's need } \\
\text { for sustainable } \\
\text { scientific and } \\
\text { technological } \\
\text { progress }\end{array}$ & $\begin{array}{l}\text { Improving the } \\
\text { comfort of the } \\
\text { lifestyle of a } \\
\text { certain social } \\
\text { group }\end{array}$ & $\begin{array}{l}\text { Minimizing } \\
\text { resource } \\
\text { consumption } \\
\text { and damage to } \\
\text { nature }\end{array}$ \\
\hline 2 & $\begin{array}{l}\text { The basis of the } \\
\text { methodology }\end{array}$ & $\begin{array}{l}\text { marketing } \\
\text { theory }\end{array}$ & $\begin{array}{l}\text { Philosophy and } \\
\text { methodology of } \\
\text { science }\end{array}$ & $\begin{array}{l}\text { Analysis of the } \\
\text { lifestyle of social } \\
\text { groups }\end{array}$ & $\begin{array}{l}\text { Stochastic, } \\
\text { simulation } \\
\text { modeling of } \\
\text { natural } \\
\text { processes }\end{array}$ \\
\hline 3 & $\begin{array}{l}\text { Development } \\
\text { product } \\
\text { (product or } \\
\text { service) }\end{array}$ & $\begin{array}{l}\text { Individual } \\
\text { product or } \\
\text { service }\end{array}$ & $\begin{array}{c}\text { Scientific } \\
\text { support for the } \\
\text { development of } \\
\text { NTO (service) }\end{array}$ & $\begin{array}{c}\text { Complex } \\
\text { product (goods } \\
\text { and services) for } \\
\text { one social group }\end{array}$ & $\begin{array}{l}\text { The product is } \\
\text { related to } \\
\text { resource } \\
\text { conservation } \\
\text { and the ecology } \\
\text { of society }\end{array}$ \\
\hline 4 & $\begin{array}{l}\text { Planning } \\
\text { horizon }\end{array}$ & $\begin{array}{l}\text { product life } \\
\text { cycle }\end{array}$ & the year 2040 & $\begin{array}{c}\text { Strategic, } \\
\text { market segment }\end{array}$ & $\begin{array}{l}\text { Long-term, } \\
\text { global }\end{array}$ \\
\hline
\end{tabular}




\begin{tabular}{|c|c|c|c|c|c|}
\hline 5 & $\begin{array}{c}\text { The object of } \\
\text { implementation } \\
\text { of the } \\
\text { innovation } \\
\text { project }\end{array}$ & $\begin{array}{l}\text { The } \\
\text { company's } \\
\text { grocery } \\
\text { basket }\end{array}$ & $\begin{array}{c}\text { Technological } \\
\text { order as a new } \\
\text { stage in the } \\
\text { development of } \\
\text { human } \\
\text { civilization }\end{array}$ & $\begin{array}{l}\text { Creation of a } \\
\text { comprehensive } \\
\text { service system } \\
\text { for the market } \\
\text { segment }\end{array}$ & $\begin{array}{c}\text { The system of } \\
\text { nature } \\
\text { conservation } \\
\text { and ensuring } \\
\text { the } \\
\text { environmental } \\
\text { interests of } \\
\text { society as a } \\
\text { whole }\end{array}$ \\
\hline 6 & $\begin{array}{l}\text { Attitude to } \\
\text { competition }\end{array}$ & $\begin{array}{l}\text { Competition } \\
\text { for a specific } \\
\text { client, market } \\
\text { segment } \\
\text { share }\end{array}$ & $\begin{array}{c}\text { It is out of } \\
\text { competition } \\
\text { due to a } \\
\text { qualitative leap } \\
\text { in technological } \\
\text { development }\end{array}$ & $\begin{array}{l}\text { The goal is to } \\
\text { avoid } \\
\text { competition by } \\
\text { creating pioneer } \\
\text { integrated } \\
\text { products }\end{array}$ & $\begin{array}{l}\text { Competition at } \\
\text { the level of } \\
\text { philosophy, } \\
\text { national idea, } \\
\text { lifestyle and } \\
\text { culture of the } \\
\text { nation }\end{array}$ \\
\hline 7 & $\begin{array}{l}\text { Key factors of } \\
\text { developer } \\
\text { competition }\end{array}$ & $\begin{array}{l}\text { Competence } \\
\text { of the } \\
\text { company's } \\
\text { personnel }\end{array}$ & $\begin{array}{l}\text { Mentality and } \\
\text { organizational } \\
\text { culture of } \\
\text { development } \\
\text { institutions of } \\
\text { the NTO }\end{array}$ & $\begin{array}{l}\text { competence and } \\
\text { organizational } \\
\text { culture of the } \\
\text { company's } \\
\text { personnel }\end{array}$ & $\begin{array}{l}\text { Organizational } \\
\text { culture of the } \\
\text { entire national } \\
\text { innovation } \\
\text { system }\end{array}$ \\
\hline 8 & $\begin{array}{c}\text { The impact of } \\
\text { the concept on } \\
\text { the market }\end{array}$ & $\begin{array}{l}\text { Impact on the } \\
\text { market } \\
\text { segment }\end{array}$ & $\begin{array}{l}\text { Qualitative } \\
\text { impact on all } \\
\text { markets }\end{array}$ & $\begin{array}{c}\text { The impact of } \\
\text { the product on } \\
\text { the market } \\
\text { segment }\end{array}$ & $\begin{array}{l}\text { The impact of } \\
\text { the } \\
\text { technological } \\
\text { system on the } \\
\text { human } \\
\text { environment }\end{array}$ \\
\hline 9 & $\begin{array}{c}\text { Criteria for } \\
\text { evaluating the } \\
\text { effectiveness of } \\
\text { an innovative } \\
\text { project }\end{array}$ & $\begin{array}{c}\text { The } \\
\text { company's } \\
\text { current profit }\end{array}$ & $\begin{array}{l}\text { Improving the } \\
\text { level of safety } \\
\text { and comfort of } \\
\text { life of the } \\
\text { population }\end{array}$ & $\begin{array}{l}\text { The cost of the } \\
\text { company }\end{array}$ & $\begin{array}{l}\text { The degree of } \\
\text { similarity of the } \\
\text { technological } \\
\text { process to } \\
\text { natural } \\
\text { processes }\end{array}$ \\
\hline
\end{tabular}

Source: developed by the author

Note: As part of the transition to NTO, there is also the idea of creating metaverses. This idea of metaverses was announced by Facebook founder Mark Zuckerberg in October 2021. At the same time, M. Zuckerberg conducted a deep rebranding of his global information system in the fall of 2021. Facebook has been renamed META. However, the essence and content of such a metaverse proposed by Zuckerberg M. have not yet been described.

The paradigm of economic efficiency of the NTO assumes that during this technological order, the costs of developing new technologies should be recouped by an additional increase in the gross domestic product of the country. These additional revenues should be obtained through the introduction of these technologies in a certain time frame. Such a paradigm assumes purposeful maximization of the number of new technologies introduced into new NTO products and existing products of previous technological structures.

The functioning of NSR stakeholders is not only sectoral, but also regional in nature. Therefore, it is necessary to synthesize a methodology for the formation of strategic plans or programs for the modernization of the country's regions adjacent to the NSR Glushchenko (2021).

The methodology of forming a strategic plan for the modernization of the country's regions in the 9th technological order may include such actions. 
1) Study of the structure and analysis of the characteristics of the structural elements of the technological basis of a certain region of the country (object of modernization).

2) Assessment of the share of technologies of each of the technological structures as part of the characteristics of the socio-economic development of the region (volume of production; contribution to the budget, number of employees, etc.).

3) Conducting a SWOT analysis (threats and opportunities of the external environment; strengths and weaknesses of the country's region).

4) Development of a plan of long-term measures aimed at adapting the region to changing external conditions.

5) Formation of a list of measures aimed at coordinating the internal environment of the region.

6) Study of the availability of conditions for the formation of new technological platforms and clusters.

7) Revision of the technological basis of enterprises and the study of the possibilities of introducing new technologies (for each type of technology) of the 9th technological order at already existing firms (enterprises) in the region.

8) Analysis and assessment of social and economic effects when implementing each of the types of technologies of the 9th technological order (NTO) at existing enterprises in the region.

9) Identification of priorities for the introduction of specific types of new technologies of the 9 th technological order. Criteria for setting priorities can be: availability of conditions for the introduction of technology; minimum payback period; shortest time for the introduction of technology; maximum economic efficiency (NPV, PI) of the technology implementation project; the possibility of multiple implementations of one technology on the largest number of firms (enterprises) or other.

10) Analysis of conditions for multiple and / or integrated implementation of one technology and / or devices of the 9th technological order in the organizations of the region and others.

As an example of a fragment of the implementation of the described strategic planning methodology, we will analyze the possibility of practical use of NTO technologies in family nomadic livestock farms in the regions of the Far North of Russia. It is important that permafrost areas in Russia make up 2/3 of its area. About $30 \%$ of the world's reserves of all minerals are located on the permafrost territory. At the same time, the studied nomadic livestock farms are of a family nature. The studied livestock farms roam the tundra together with their herds of deer. Such families of reindeer herders live in makeshift yurts. A yurt is a kind of tent that is covered with deer skins. Such animal breeders move on reindeer sleds (a kind of horse-drawn traction). This type of reindeer sled can be attributed to the second technological order. The second technological mode is called "horse-drawn traction". We are investigating the possibility of introducing NTO technologies into the ecosystem of the vital activity of such nomadic households of the peoples of the Far North of Russia (or other desert regions of the world).

1) Nanotechnology can be practically used for the following purposes: increasing the wear resistance and strength of the frame of the yurt, increasing the strength, wear resistance and thermal insulation properties of the materials of the outer covering of the yurt (skin substitute), etc. 
2) Nanotechnologies and biotechnologies can be used in the production of medicines, for example, drugs used to increase immunity (livestock breeders, deer), in particular, we can talk about medical drugs such as "Kagocel"?

3) Neurotechnologies can be used to measure the characteristics of the physical condition of people (reindeer herders) and/or their animals (deer). Such a practical application of neurotechnologies can help prevent: overstrain of people and their deer, which will reduce the likelihood of human diseases and the risks of livestock deaths, and more.

4) Radar beacons and other types of information devices and technologies can be used in practice to accurately determine the location of a reindeer herders' camp and/or a separate reindeer team. Such information will help if there is a need for prompt assistance to residents of the Far North in emergency situations. Such prompt assistance can reduce the risk of death of people and animals in difficult weather conditions and more. For example, using such information, it is possible to drop medicines, food and other things from a helicopter. In addition, the availability of such information will increase the degree of state control of the territories of the Far North.

To modernize reindeer herders' homes (yurts), reindeer sleds can be used as part of the conversion, for example, aviation materials and technologies. In particular, existing technologies for the production of composite materials from the field of aviation materials and others can be used.

It may be proposed to create mini-factories for processing deer meat and/or processing deer skins, etc. These products can be exported (entered into economic circulation) and used in the operation of the NSR. For example, meat and canned food can be used to feed the crews and passengers of ships and others.

The proposed targeted modernization of the ecosystem of the way of life of the peoples of the Far North of Russia through the integrated introduction of technologies of the 9th technological way will help: reduce the risks to human life and health; increase the life expectancy of the local population (reindeer herders); create conditions for increasing the herd of animals; create more comfortable and safe living conditions for the local population.

Programs for the modernization of the ecosystem of the vital activity of small nomadic peoples of the North, programs for the practical use of technologies of the 9th technological order could be international. An increase in the scale of implementation of such programs can reduce the cost of sets of implemented technical means of a new technological order. This kind of effect of reducing the cost of equipment due to an increase in its production in the economy is known. This effect is referred to as the "experience curve" or "production scale effect". This law of economics sounds like this: every time the volume of production increases by two, the cost of production decreases by $20 \%$.

\section{DISCUSSION}

The materials of this article show that in 2021, as part of the formation of a new 9th technological order, they are actively looking for new concepts and forms of doing business, developing new technologies. At the same time, science does not have time to respond to the requests of practice. Science does not perform the function of advanced scientific research. This state of affairs creates risks for the investment activities of the state and private companies. At the same time, companies cannot wait, they must implement their modernization programs in the 
interests of maintaining their own competitiveness. In particular, such a lag in scientific research from the needs of practice is observed in the field of ecosystems, nature-like technologies, metasystem development plans.

To increase the level of scientific support for development processes, we can recommend:

- to increase the effectiveness of measures for the integration of sciencepractice-education?

- to form new methods for the integration of science and practice Glushchenko (2019)?

- to increase the level of involvement of scientific and pedagogical workers in the process of modernization of the national economy;

- increase the number of new venture investment institutions in innovative projects Glushchenko (2021)?

- improve institutional relations between companies and the scientific community;

- Take measures to reduce the number and intensity of conflicts in the NTO Kolchinsky and T.D. (2018) and others.

To solve these problems of scientific support for the development of NTO, this article proposes to develop a special program to improve the effectiveness of the integration of science-education and practice.

The study of the NSR as a system-forming link of the ecosystem of the Far North of Russia poses fundamentally new scientific and practical tasks for the developers of the image of the future and the modernization project of this international and, at the same time, internal transport corridor. Modernization of the NSR and the entire ecosystem of the regions of the Far North of Russia will help reduce the risks and the problem of so-called northern imports. Northern delivery is a transport operation carried out in summer to deliver in summer all the goods necessary for winter to these regions.

At the same time, in 2021, the theory and practice of system engineering and the ecosystem approach in the world and Russia are not yet sufficiently developed. Therefore, it can be recommended to create departments in transport universities: theory of transport systems; system design of transport complexes, system engineering of transport.

The creation of such departments will contribute to: accelerating the processes of developing the concept of creating ecosystems, metasystems in the economy; modernization of the NSR and other transport corridors within the framework of the ecosystem approach. In the process of developing a methodology for system design in transport, the result of the work can be useful Borovik and Doroshenko (2020), Kovalchuk (2021), Glushchenko et al. (2017).

One of the directions of ecosystem development in transport during the NTO period may be the development of neurotechnologies.

It can be recommended to create departments of neurotechnology in transport universities.

At the same time, it should be borne in mind that in the field of higher education during the NTO period there will be a tendency to switch to higher project education Glushchenko (2021). In general, the trend of transition from subject and competence-based education to a system-activity approach in higher education will continue. In additional professional education, the trend of education development will continue, aimed at changing the mentality and thought process of students. Gradually, this trend will spread to university education. It should be borne in mind 
that in order to spread competence-based higher education and a system-activity approach, it is necessary to expand the scope of training of teaching staff.

The analysis shows that in order to competently conduct classes within the framework of project higher education, a professor must have knowledge in several specialties simultaneously: technical sciences; economics; finance; management; marketing; investment; design, pricing, commerce, insurance, entrepreneurship and others. Such a complex amount of knowledge is now possessed by a smaller part of modern teachers. This may slow down the introduction of higher project education into the practice of universities.

With the development of neurotechnological education and mechanical engineering during the NTO period, it should be borne in mind that, presumably, a significant amount of scientific knowledge and practical developments can be accumulated in the field of neurotechnology in the field of aviation. Is it possible to extend this reserve to all transport engineering? The methodology of modernization of the vehicles themselves is described in works Macheret (2021), Glushchenko (2021), Glushchenko (2021). The methodology of modernization of mechanical engineering products has been tested by the author of this article in educational projects and shows good practical results. It can be expected that the development of the NSR ecosystem will be accompanied by the formation of new social and professional institutions Glushchenko (2021). At the same time, the development of a strategy and program for the modernization of the NSR as an ecosystem of a number of regions adjacent to the NSR may generate socio-economic transformations and mental conflicts of stakeholders in these processes Glushchenko (2021). The following factors can contribute to the emergence of conflict situations during the modernization of the ecosystem of the NSR: competition of scientific ideas and concepts; competition of modes of transport within the NSR; competition of the regions of the country; solving the problem of alternative investments and other factors. There are risks of conflicts between scientific ideas Kolchinsky et al. (2018). The methodological results of this article can be useful in the modernization of transport ecosystems of various hierarchical levels (global, national, regional, municipal) and various types of international, national, interregional transport corridors during the NTO period.

\section{CONCLUSION}

The article forms a methodology for the modernization of transport ecosystems, discusses conceptual approaches that can be implemented in the process of modernization of the Northern Sea Route (NSR) as an ecosystem based on the achievements of science and technology of the ninth technological order. The article presents a historical, systematic analysis of the development of 9 technological orders of development of modes of transport in the process of progress of human civilization. The paper presents a comparative analysis of approaches to the modernization of the NSR: the concept of the effectiveness of technological structures; marketing approach; ecosystem and convergent (naturelike) approaches. A methodology was proposed for drawing up strategic plans for the modernization of regions adjacent to the NSR and others. The article discusses the problems of increasing the efficiency of scientific support for the processes of formation of the ninth technological order. The paper examines the directions of development and market integration of science, practice and education in the period of the ninth technological order. The results of this article will be useful in creating an image of the future ecosystem of the NSR and other international transport corridors. The results of this article can be useful in the modernization of other types 
of man-made ecosystems, transport ecosystems and international transport corridors (Baikal-Amur Mainline, the Great Silk Road and others).

\section{REFERENCES}

Aivazov A. (2012). The periodic system of world capitalist development. [Electronic resource] Access mode. Html, free. Cover from the screen. Yaz. Rus. (accessed December 2015). Retrieved from http://ajvazov.ru/articles/periodicheskaya-sistema-mirovogokapitalisticheskogo-razvitiya

Arrighi G. (1994). The Long Twentieth Century : Money, Power and the Origins of our Times. L. : Verso.

Borovik G.G., Doroshenko K.V. (2020) The concept of an ecosystem, types of ecosystems and the main differences between natural and anthropogenic ecosystems//Student Forum. No. 30 (123). pp. 23-24.

Gerasimenko E.V. (2020) Modernization of railway transport//Student Bulletin. No. 33-2 (131). pp. 51-52.

Glazyev S.Yu. (2016) World economic patterns in global economic development//Economics and mathematical methods. Vol. 52. No. 2. pp. 329. Retrieved from https://doi.org/10.2753/PET1061-1991520501

Glushchenko V. V. (2019) Mechanism of increase of efficiency of integration of science education practices in the post-industrial conditions // Kazakhstan Science Journal, no. 8 (9), 2, pp. 25-40. Retrieved from https://sciencejournal.press/sj/article/view/107/98

Glushchenko V. V. (2021) The Ecosystem approach in the modernization of the Northern sea route during the formation of the 8-th technological structure//Kazakhstan Science Journal. Vol. 4. No. 9 (34). P. 19-32. (accessed: 11/29/2021). Retrieved from https://sciencejournal.press/sj/article/view/274/222

Glushchenko V.V. (2019) Mission, goals and objectives of the general theory of transport systems// Kazakhstan Science Journal, No. 4, pp. 58-84. Retrieved from https://sciencejournal.press/sj/article/view/66/68

Glushchenko V.V. (2021) The concept of customization of scientific and pedagogical activity in industrial engineering universities//Bulletin of Mechanical Engineering. No. 4. pp. 81-88. Retrieved from https://doi.org/10.36652/0042-4633-2021-4-81-88

Glushchenko, V. V. (2021). Creating a model of the future of the eighth technological order. International Journal of Engineering Science Technologies, 5(5), 1740. Retrieved from https://doi.org/10.29121/ijoest.v5.i5.2021.217

Glushchenko, V. V. (2021). Management System for the Development of Industrial Social Relations of a New Technological Order. International Journal of Scientific Advances (IJSCIA), Volume 2| Issue 4: May-Jun 2021, Pages 554563 , URL: (accessed 29.07.2021). Retrieved from https://www.ijscia.com/wp-content/uploads/2021/07/Volume2-Issue4Jul-Sep-No.128-554-563.pdf

Glushchenko, V. V. (2021). Strategic planning of organizations ' transition to the sixth technological order in the national economy// International Journal of Engineering Science Technologies, 5(1), 30 - 46. Retrieved from https://doi.org/10.29121/ijoest.v5.i1.2021.159 
Glushchenko, V. V. (2021). The mission and essence of the theory of technological orders. International Journal of Engineering Science Technologies, 5(4), 6582. Retrieved from https://doi.org/10.29121/ijoest.v5.i4.2021.205

Glushchenko, V.V., Glushchenko, I.I., Plakhotin, E.O., Shinaeva, A.I. (2017) Management of Neuromarketing in the Service Sector on Railway Transport [Electronic Resource] // Youth Research Journal. No. 11 (24), P. 201-212. (Released 11.17.2017). Retrieved from http://www.mnvnauka.ru/2017/11/Glushchenko.pdf

Gnatyuk A.N. (2015) Urban public transport. death without modernization//Bulletin of the Institute of Problems of Natural Monopolies: Railway Engineering. No. 1 (29). p. 16.

Kolchinsky E.I. N.I. Vavilov and T.D. (2018) Lysenko in the space of historical and scientific discussions//Nature. No. 1 (1229). pp. 3-14.

Kovalchuk M.V. (2021) Nature-like (convergent) technologies - global threats and challenges//SPbPU Science Weeks, Peter the Great St. Petersburg Polytechnic University, Retrieved from https://www.youtube.com/user/SPBMEDIA influence//Transport of the Russian Federation. No. 3 (94). pp. 3-8.

Mesarovich M., Mako D., Takahara I. (1973) Theory of hierarchical multilevel systems. - M.: Mir. - 344 p.

Protsenko V. M. (2020) Conceptual aspects of the intensification of management of economic behavior of industrial enterprises of railway transport in the conditions of neoindustrial modernization//problems of Economics (Kharkiv). № 2 (44). Pp. 281-287.

Semenov A.V., Kulikovskaya I.S., Sharanova E.G. (2021) Legal regulation of certaine issue of modernization of infrastructure in the field of maritime transport//Bulletin of the Admiral F.F. Ushakov State Maritime University. No. 2 (35). pp. 70-71.

Shakhbanov R. B., Azizova L. R. (2019) Improvement of system analysis by means of enterprise activity analysis//In the collection: Topical issues of the theory and practice of the development of scientific research. collection of articles of the International Scientific and Practical Conference. S. 12-16.

Valery Vladimirovich Glushchenko. (2021). Project approach in higher engineering education// International Journal of Engineering Technologies and Management Research, 8(3), 36-44. Retrieved from https://doi.org/10.29121/ijetmr.v8.i3.2021.906

Valery Vladimirovich Glushchenko. (2021). Technology platform for venture capital investments in innovations in the conditions of the sixth technological order// International Journal of Engineering Technologies and Management Research, 8(3), 27-35. Retrieved from https://doi.org/10.29121/ijetmr.v8.i3.2021.900

Vasiliev D.V., Mazaev N.A. (2020) Railway transport as a factor of modernization of the Russian Empire (based on materials of the pre-revolutionary press)//Bulletin of the Orenburg State Pedagogical University. Electronic scientific journal. No. 4 (36). pp. 247-259. Retrieved from https://doi.org/10.32516/2303-9922.2020.36.14

Vladimirov A.A. (2016) Modernization of technical means of water transport//In the collection: Problems of use and innovative development of inland 
waterways in the basins of great rivers. Proceedings of the International Scientific and Industrial Forum. p. 41. 